\title{
SHARKA-RESISTANT PLUM HYBRIDS AND CULTIVARS FROM THE PLUM BREEDING PROGRAMME AT HOHENHEIM
}

\author{
Walter Hartmann \\ Filderstadt, Erikaweg 5, GERMANY \\ Corresponding author, drwalthart@yahoo.de
}

Communicated by Edite Kaufmane

\begin{abstract}
Sharka (PPV) is one of the most dangerous viruses in fruit growing. More and more fruit growers are unsatisfied with the resistances or tolerance of plum varieties cultivated today. With the utilisation of the hypersensitive reaction to PPV in breeding we developed 'Jojo' as the first absolutely resistant cultivar in the field. Most interesting now is the development of new sharka-resistant cultivars, especially in three points: extension of ripening range, better fruit size, and high fruit quality. In a new breeding programme, we obtained many hypersensitive clones. After testing in different regions, some interesting resistant clones and cultivars were selected and are presented here.
\end{abstract}

Key words: Prunus domestica, Sharka, PPV, hypersensitivity.

\section{INTRODUCTION}

Sharka disease (Plum pox virus, PPV) has spread from the European continent towards the most important Prunus-growing areas around the world. Németh (1986), Kegler and Hartmann (1998) and Nemchinov et al. (1998) have reviewed the importance of plum pox on European stone-fruit production. Plum pox virus is present, or has occurred, in practically all European countries, but to very different extent. Sharka disease is particularly serious in the fruitproducing areas of Central and Eastern Europe. Virus infection can lead to considerable yield losses, reaching $83-100 \%$ in highly susceptible varieties (Kegler and Hartmann, 1998; Nemchinov et al., 1998). There are considerable differences in susceptibility between the cultivars available for use in countries where infection is widespread (Hamdorf, 1986; Kegler et al., 1986). Losses in European plum-fruit production are estimated at 1.5 million metric tons per year, representing 45 million metric tons in the last 30 years with an estimated value of 5400 million euros (with an average price of 0.12 Euros $/ \mathrm{kg}$ ). An evaluation of the global cost associated with plum pox management worldwide, excluding indirect trade costs, has been estimated in the last three decades as more than 10000 million euros (Cambra et al., 2006).

More and more fruit growers are unsatisfied with the resistances or tolerance to PPV of plum cultivars grown today.
This is resulting from the quantitative resistance, which depends on stress by climatic conditions. We can also notice an increase of the symptoms in warmer and dryer years of the last decade. From different experiments and from our experience we can conclude that all factors that have stressed a tree result in an increase of the virus multiplication and its symptoms. We can also observe an increase of the symptoms on older trees if they were infected as young trees. These connections may explain different reactions of resistant varieties from year to year and from region to region.

The degree of resistance in the last years has resulted not only in more damaged fruits, but also in lower yields and earlier ripening. An improvement of this situation is only possible by cultivation of immune or absolutely resistant cultivars. Because there are no immune plums, a new strategy in resistance breeding was required. Another type of resistance, which appears as a typical hypersensitivity and may resemble a localised resistance, was found by Kegler $e t$ al. in 1986. A proposal was made by Hartmann (1998a) for utilisation of the hypersensitive reaction to PPV. In the breeding material at Hohenheim, we found some hybrids, derived from cultivar 'Ortenauer', with hypersensitive reaction and field resistance. Many extensive tests resulted in the introduction of the first absolutely PPV-resistant cultivar 'Jojo' (Hartmann and Petruschke, 2000). This new variety has been tested since 1992 in different sharka-infected 
orchards and also in some sharka tolerance tests. In the field no infected plants were ever found, which indicates absolute resistance. This type of hypersensitivity is effective against a broad range of PPV isolates and can lead to a stable resistance in the field. From a practical point of view, the lack of infected trees in the orchard is a priority factor in planning management. With the new absolutely sharka-resistant variety 'Jojo', introduced in 1999, the fruit grower has the guarantee of PPV-free trees, as proved in artificial infection tests with aphids in the glasshouse and demonstrated in longterm field tests.

An alternative to the traditional methods of cultivar development and one that provides new gene resources for resistance breeding is the transformation of plants with viral genes, such as those for coat protein (CP). An example of successful application of this approach is the plum clone C5 containing the PPV-CP transgene insert (Scorza et al., 1994). The absence of virus spread is caused by RNR interference resulting in silencing, which is natural adaptive protection against viruses. The clone was named 'HoneySweet' and has been cleared for cultivation in USA. 'HoneySweet' was field-tested in some European countries (Poland, Spain, and Romania). The test confirmed some adaptive protection against viruses. The cultivar was resistant to PPV, but it was found that 'HoneySweet' is not absolutely immune. Sharka symptoms were found on leaves near the grafting site, although no systemic virus spread was found (Scorza et al., 2010). However, the problem is that in most European countries the consumers do not want genetically modified (GM) fruits. A number of EU Members have prohibited individual authorized genetically modified organisms (GMOs) or GM seeds, including Austria, Hungary, France, Greece, Germany, and Luxembourg. Under the current legal regime, EU Members may restrict or totally ban cultivation in their territories.

In the meantime, 'Jojo' has been growing for more than 30 years in heavily infected orchards and has always been free of PPV. This is the conclusive proof of the effectiveness of hypersensitivity. Similar results were found in Poland (Malinowski et al., 2013), in Slovenia (Marn et al., 2014) and in many other European countries.

'Jojo' has proved also to be a good parent in breeding cultivars resistant to PPV not only in Germany, but also in Poland (Zurawicz et al., 2013). Many resistant clones have been developed in the Hohenheim breeding programme, which have been tested in different regions, and we are hoping to obtain some more resistant cultivars that ripen over the whole season. In the meantime, we have developed four hypersensitive cultivars named 'Jojo', 'Jofela', 'Joganta', and 'Jolina', and many promising clones have been tested in different regions. The results are presented in this paper.

\section{MATERIAL AND METHODS}

'Jojo' and some hypersensitive clones were used as donators for crossing to obtain hypersensitive hybrids. The breeding aims were: extending ripening time, high and regular cropping, fruit size, and, most important, fruit quality. After selection for the breeding aims, promising seedlings were grafted on rootstock Wavit and planted in different orchards for regional tests, and planted also in a special sharka resistance test. For the clones, a glasshouse test for hypersensitive reaction was also conducted, by double grafting onto myrobalan rootstocks with PPV infected interstems (Kegler et al., 1994). The reaction of these plants was recorded and an index of hypersensitivity was calculated as described by Neumüller and Hartmann (2008).

The yield of the clones was estimated by the international scale from one (single fruits) to nine (over cropping). The fruit weight was determined by average weight of 30 fruits. Ten fruits were analysed for soluble solid content by refractometer, and the taste was judged according a scale from 1 (very poor) to 9 (excellent). The total pomological value of a clone was also given by a scale from 1 to 9 , with 9 as the best pomological value. Data analysis of average fruit weight and Brix\% was done with MS Excel and SPSS. The obtained data were processed using analysis of variance and the Tukey test. Groups were ranked as significantly different with $99 \%$ confidence level (a indicates the smallest value).

\section{RESULTS}

Inheritance of hypersensitivity. In the breeding material of Hohenheim we found altogether 575 clones that reacted as strongly hypersensitive, i.e. with a hypersensitivity index of more than 0.70 . The number of hypersensitive seedlings depended on the crossing combination (Table 1). The best results were obtained when both crossing partners were hypersensitive reaction, for example, 'Jojo' $\times$ Nr. 4465 resulted in $78 \%$ of hypersensitive seedlings. Four cultivars were introduced in the last years and two in spring 2018.

Main breeding aims. Most of the interest in our plum breeding programme was paid to the improvement of sharka resistant varieties, especially in three points: 1) extension of ripening; 2) larger fruits; 3) high fruit quality.

Table 1

INHERITANCE OF HYPERSENSITIVITY: COMBINATIONS OF CROSSING, NUMBERS OF SEEDLINGS AND PERCENTAGE OF HYPERSENSITIVE CLONES

\begin{tabular}{l|c|c}
\hline \multicolumn{1}{c|}{ Combination } & Number of seedlings & \% Hypersensitive \\
\hline Jojo $\times$ Jojo & 129 & 55 \\
Jojo $\times$ Fellenberg & 128 & 45 \\
Jojo $\times$ Haganta & 105 & 29 \\
HZ Wolff $\times$ Jojo & 133 & 22 \\
Jojo $\times$ HZ Schüfer & 55 & 22 \\
Jojo $\times$ HZ Gunser & 20 & 40 \\
Jojo $\times$ Harbella & 87 & 36 \\
Jojo $\times$ 1468 & 106 & 15 \\
Jojo $\times$ Nr. 4465 & 119 & 78
\end{tabular}


size), excellent fruit quality, sugar content between SHARKA-RESISTANT CULTIVARS AND CLONES, AND THEIR PARENTS

\begin{tabular}{ll}
\hline \multicolumn{1}{c}{ Cultivar, clone Nr. } & \multicolumn{1}{c}{ Crossing partner } \\
\hline Jojo & Ortenauer $\times$ Stanly \\
Jofela, 7344, 7410 & Jojo $\times$ Felsina \\
Jolina, Joganta, 7245 & Jojo $\times$ Haganta \\
Herrenberger late & Jojo $\times$ Hauszwetschge \\
6364 & Jojo $\times$ Hanita \\
7092 & Jojo $\times$ Nr. 1468 \\
7576,7627 & Jojo $\times$ Cacaks fruitful \\
7965 & Nr. $4465 \times$ Haganta \\
8404 & Tegera $\times 6482$ \\
8575 & $4465 \times$ Haganta \\
$8616,8626,8627,8630,8709$ & Nr.4517 $\times$ Haganta \\
8670 & Nancy Mirabele $\times 6217$
\end{tabular}

In breeding you have to look for relevant donators to achieve the breeding aims. Table 2 presents the sharka-resistant cultivars and some interesting resistant clones of our breeding work and the corresponding crossing partner.

Extension of ripening. Ripening of plums in Hohenheim region starts at the end of June and continues till the middle of September. By breeding, the season was extended till the beginning of October. In Germany plums are grouped by six different ripening times (Fig. 1).

Early ripening. It is not easy to obtain hypersensitive plums with early ripening (Table 3 ). Thus far, we have obtained only one interesting hybrid (Nr. 8404) resulting from crossing 'Tegera' with the hypersensitive clone Nr. 6482. The clone Nr. 8404 ripens at the same time or some days later than 'Katinka' and the fruits are slightly larger (but without significant differences). The fruits have firm and orange flesh, with good taste. Breeding hypersensitive early ripe plums should be an important breeding point in the future.

Medium late ripening. The ripening of sharka-resistant plums extends from the middle to the end of July to the beginning of October. The four clones ripening in August have a fruit weight between $32-53 \mathrm{~g}$ (medium to large in

$20.7-23.2 \%$ Brix and high taste estimation value. Clone Nr. 6621 is similar in size and fruit quality to 'Fellenberg', but for good cropping of this clone good weather conditions at blossom time are necessary. Good croppers with high fruit quality are Nr. 7533 and 8630. Both had high yield also in 2017 when there was extreme spring frost damages.

Nr. 7533 was released as 'Herrenberger Early' in February 2018. It is a variety intended only for this region. Herrenberg region was famous for the production of 'Hauszwetschge' with excellent quality, but since sharka has become a big problem causing infection of young trees within 2-3 years, this variety is no longer recommended.

'Herrenberger Early' is an annually well cropping cultivar, with dark blue colour and good fruit quality and should substitute the variety 'Hauszwetschge'.

Late ripening plums. September is the month of plums. It is therefore not surprizing that most of the hypersensitive plums are ripe in this month.

Plums ripening at beginning to middle of September are considered as late. This is the ripening time of 'Hauszwetschge'. In the last years, we selected six interesting clones ripening in this period. One of them was introduced as 'Jofela'. 'Jofela' has excellent fruit and eating quality. The cultivar is partially self-fertile and a pollinator would provide more regular yields.

Clone Nr. 7410 also has excellent fruit quality, high sugar content, firm fruits, as the consumers like today. The clones Nr. 6364 and 7235 have fruits with more than $59 \mathrm{~g}$, with good taste.

Clone Nr. 6410 is also a plum only for the region of Herrenberg, named 'Herrenberger late'. This cultivar is similar in quality and shape to 'Hauszwetschge' and is an excellent substitution for the former predominating variety. The new cultivar is a regular cropper because it is less sensitive than 'Hauszwetschge' to bad weather conditions at blossom time. Ripening is together with late ripening clones of 'Hauszwetschge'.

Fig. 1. Ripening time of standard cultivars

\begin{tabular}{|c|c|c|c|c|c|c|c|c|c|c|c|c|c|c|c|c|}
\hline \multirow{3}{*}{$\begin{array}{l}\text { Ripening } \\
\text { time }\end{array}$} & \multirow{3}{*}{$\begin{array}{l}\text { Standard } \\
\text { cultivars }\end{array}$} & \multicolumn{15}{|c|}{ Month of harvesting } \\
\hline & & \multicolumn{3}{|c|}{ June } & \multicolumn{3}{|c|}{ July } & \multicolumn{3}{|c|}{ August } & \multicolumn{3}{|c|}{ September } & \multicolumn{3}{|c|}{ October } \\
\hline & & $\mathrm{B}$ & M & $\mathrm{E}$ & $\mathrm{B}$ & M & $\mathrm{E}$ & $\mathrm{B}$ & $\mathrm{M}$ & $\mathrm{E}$ & $\mathrm{B}$ & M & $\mathrm{E}$ & $\mathrm{B}$ & M & $\mathrm{E}$ \\
\hline Very early & Ruth Gerstetter & & & & & & & & & & & & & & & \\
\hline Early & Katinka & & & & & & & & & & & & & & & \\
\hline Middle early & Cacaks lepotica & & & & & & & & & & & & & & & \\
\hline Middle late & Cacaks fruitful & & & & & & & & & & & & & & & \\
\hline Late & Hauszwetschge & & & & & & & & & & & & & & & \\
\hline Very late & Presenta & & & & & & & & & & & & & & & \\
\hline
\end{tabular}

$\mathrm{B}$, beginning of month; $\mathrm{M}$, middle of month; $\mathrm{E}$, end of month 
CHARACTERISATION OF CLONES AND HYBRIDS (GROUPED BY RIPENING TIME, SHARKA RESISTANCE, HYPERSENSITIVENESS)

\begin{tabular}{|c|c|c|c|c|c|c|c|}
\hline \multicolumn{8}{|c|}{ Early ripening hypersensitive clone } \\
\hline Clone Nr. & Harvesting time & Yield 1-9 & $\begin{array}{c}\text { Average fruit } \\
\text { weight, } g\end{array}$ & Brix \% & Taste 1-9 & $\begin{array}{c}\text { Stone separa- } \\
\text { tion } 1-9\end{array}$ & $\begin{array}{c}\text { Overall score } \\
1-9\end{array}$ \\
\hline 8404 & middle to end of July & $4-7$ & $27.4^{\mathrm{a}}$ & $16.9^{\mathrm{a}}$ & 7 & $7-9$ & 7 \\
\hline Katinka (standard) & middle of July & 7 & $26^{\mathrm{a}}$ & $15.3^{\mathrm{a}}$ & 7 & 7 & 7 \\
\hline \multicolumn{8}{|c|}{ Medium late ripening hypersensitive clones and cultivars } \\
\hline 7945 & middle of August & $6-7$ & $44^{\mathrm{c}}$ & $21.1^{\mathrm{b}}$ & 7 & 9 & 7 \\
\hline 6621 & middle to end of August & $5-7$ & $32^{\mathrm{a}}$ & $23.2^{\mathrm{b}}$ & 8 & 7 & 8 \\
\hline 7344 & & $5-7$ & $34^{\mathrm{ab}}$ & $20.7^{\mathrm{b}}$ & 7 & 9 & 8 \\
\hline 8630 & end of August & $6-8$ & $53^{\mathrm{d}}$ & $23.1^{\mathrm{b}}$ & 9 & 9 & 8 \\
\hline 7533 (Herrenberger Early) & end of August to middle of September & $6-7$ & $34^{\mathrm{ab}}$ & $21.1^{\mathrm{b}}$ & 7 & 7 & 8 \\
\hline Joganta & & $6-9$ & $81^{\mathrm{e}}$ & $22.7^{\mathrm{b}}$ & $7-8$ & $6-8$ & $7-8$ \\
\hline \multicolumn{8}{|c|}{ Late ripening sharka resistant plum hybrids } \\
\hline 7092 & beginning to middle of September & $6-7$ & $44^{\mathrm{c}}$ & $22.9^{\mathrm{b}}$ & 7 & 7 & 7 \\
\hline 7235 & & 7 & $61^{\mathrm{de}}$ & $22.5^{\mathrm{b}}$ & 8 & 9 & 8 \\
\hline 6410 & & 7 & $47^{\mathrm{c}}$ & $23.1^{\mathrm{b}}$ & 7 & $7-8$ & 7 \\
\hline \multicolumn{8}{|c|}{ Late ripening sharka resistant clones and cultivar with high to excellent fruit quality } \\
\hline 7533 & beginning of September & $6-7$ & $34^{\mathrm{ab}}$ & $23.1^{\mathrm{b}}$ & 7 & 7 & 8 \\
\hline 6364 & & $6-7$ & $54^{\mathrm{d}}$ & $23.8^{\mathrm{b}}$ & 9 & 7 & 8 \\
\hline 7245 & & $6-7$ & $38^{\mathrm{b}}$ & $25.5^{\mathrm{c}}$ & 9 & 6 & 7 \\
\hline 8630 & & $6-8$ & $53^{\mathrm{d}}$ & $23.1^{\mathrm{b}}$ & 9 & 9 & 8 \\
\hline 7410 & & $6-7$ & $33^{\mathrm{ab}}$ & $23.8^{\mathrm{b}}$ & 9 & 7 & 8 \\
\hline Jofela & & $6-8$ & $38^{\mathrm{b}}$ & $25.3^{\mathrm{c}}$ & 9 & 7 & 8 \\
\hline \multicolumn{8}{|c|}{ Very late ripening cultivars and hybrid } \\
\hline Presenta & middle to end of September & 7 & $31^{\mathrm{a}}$ & $19.0^{\mathrm{ab}}$ & 7 & 7 & 7 \\
\hline Jolina & & $6-7$ & $52^{\mathrm{d}}$ & $26.1^{\mathrm{c}}$ & 7 & $7-8$ & 7 \\
\hline 7104 & end of September & 7 & 53 & $23.8^{\mathrm{b}}$ & 8 & 8 & 8 \\
\hline \multicolumn{8}{|c|}{ Late and very late ripening hypersensitive clones } \\
\hline 8626 & middle to end of September & $6-7$ & $45^{\mathrm{c}}$ & $27.3^{\mathrm{d}}$ & 9 & 7 & 8 \\
\hline 8627 & & $5-7$ & $55^{\mathrm{d}}$ & $26.8^{\mathrm{cd}}$ & 9 & 9 & 8 \\
\hline 8622 & end of September & $5-7$ & $43^{c}$ & $27.0^{\mathrm{d}}$ & 9 & 9 & 8 \\
\hline 8709 & & $6-7$ & $44^{\mathrm{c}}$ & $24.9^{c}$ & 8 & 7 & 8 \\
\hline 8616 & & $6-8$ & $42^{c}$ & $24.9^{\mathrm{c}}$ & 8 & 7 & 8 \\
\hline
\end{tabular}

Very late ripening plums. Plums that ripen from the middle to end of September are late ripening; this is the ripening time of cultivar 'Presenta'. In our breeding we obtained plums that ripen later than this variety. The cultivar 'Jolina' originated from a crossing between 'Jojo' with 'Haganta' and was introduced in 2013. The cultivar is self-fertile and flowering medium to early. 'Jolina' comes early into cropping and has a regular high yield. The dark blue fruits had the average weight $57 \mathrm{~g}$ (during five years $43-70 \mathrm{~g}$ ) and a diameter between 40 to $45 \mathrm{~mm}$ (during five years $40-50 \mathrm{~mm}$ ). The flesh is firm and juicy, rich in taste, with very high sugar content (21.6-28.9\% Brix) and with greenish to yellow colour. Interesting very late ripe plums were obtained by crossing the sharka-resistant clone $\mathrm{Nr}$. 4517 with 'Haganta'. These were clones Nr. 8616, 8622 , and 8709 , all with excellent taste and high sugar content.
Fruit size. Fruit weight is an important selection criterion in breeding. Fruit size $30-40 \mathrm{~g}$ is most demanded in Germany. However, we also selected three hypersensitive clones with fruit weight between 40 and $50 \mathrm{~g}$. They all are ripening very late and have high fruit quality with very good taste. All these clones are progenies from a crossing of clone $\mathrm{Nr}$. $4517 \times$ 'Haganta'.

In many European countries the market wants big fruits, more than $50 \mathrm{~g}$, for selling as table fruits. From our breeding work we introduced two cultivars with large fruits, the very late ripening 'Jolina' with $52 \mathrm{~g}$ and the late ripening 'Joganta' with $76 \mathrm{~g}$. In the last eight years the average fruit weight of 'Joganta' was from 53 to $108 \mathrm{~g}$ (Table 3). There are also three other clones with large fruits: the late ripening clones Nr. 8630 (53 g), Nr. 6364 (52 g), and the very late ripening clone $\mathrm{Nr} .8627$ (55 g). 
Fruit quality. Fruit quality means colour, firmness, free stone and most importantly — taste. The fruit should be dark blue with a heavy bloom and good firmness. Very important is also easy stone separation from the fruit flesh. However, taste is most important, which depends on the sugar content and a balanced ratio of sugars and acids.

High fruit quality was shown by 'Jofela' and clones $\mathrm{Nr}$. 6364, 6621, 7245, and Nr. 8627, with a balanced ratio of sugar to acid content. The clone Nr. 7533 was more sweet.

The clones Nr. 7410 and Nr. 8630 had excellent fruit quality for today's market and had firm fruits. The consumers today prefer such firm fruits with high sugar content and not so much acid.

Fruit quality must be considered together with the ripening time. It is a rule that later fruit ripening is associated with sweetness (usually characterised by soluble solids content). The late ripening clones have a soluble solids content of 22.0 to $25.3 \%$ Brix. The taste of the fruits is from good to very good, or excellent.

Very late ripening clones have a sugar content of $25 \%$ Brix and more. The taste of these five clones is from good to very good, till excellent (Table 1). All these clones are progenies of a crossing of $\mathrm{Nr} .4517 \times$ 'Haganta'.

\section{DISCUSSION}

Hypersensitive clones were used as donators for crossing to obtain hypersensitive hybrids in the plum breeding programme at Hohenheim. The breeding aims were: extending of the ripening period, high and regular cropping, fruit size and most important, fruit quality.

Ripening time. With the new clones, the ripening time was extended from the end of August to the beginning to October. These do not include the hypersensitive clones that ripen early, but many additional crossings have been made at Weihenstephan and at the Bavarian fruit centre by Michael Neumüller.

Fruit quality. Many of the regionally tested hypersensitive clones have a high level of fruit quality. Most have more than $20 \%$ Brix, some more than $25 \%$. Such clones with high sugar content were excellent in taste, with firm fruits and eating quality better than 'Hauszwetschge'. Some of the clones can replace this variety, because they are also better in regular cropping and not so sensitive to heat damage.

Fruit size. Most of the cultivars with large fruits are not satisfactory in taste. However, big fruits are especially preferred for eating and high fruit quality is essential. Most of the new large-fruited cultivars have good to excellent taste and fruit quality, with Brix content more than $21 \%$, till $26 \%$. A good donator for fruit size and also high fruit quality is the cultivar 'Haganta'.

'Jojo' and also clone Nr. 4517 have been proven as good parents in breeding cultivars resistant to PPV. The resis- tance by hypersensibility depends from infection doses of virus. We can infect 'Jojo' in a glasshouse by massive infection with sharka virus, but in the field the cultivar has been resistant for more than 30 years. Normally, the infection takes place by infection of aphids carrying only a small virus dose. There may be another situation when aphids infect the suckers of rootstock. Virus content may be higher and the variety can theoretically be infected. For this reason, we need also sharka resistant rootstocks. A combination of hypersensitive cultivars and also hypersensitive rootstock will prevent any infection. 'Docera 6' und 'Dospina 235' represent two hypersensitive rootstocks from our breeding programme, which are on the market.

\section{CONCLUSION}

With the new hypersensitive cultivars and also rootstocks the fruit grower can cultivate plums also in heavily sharka-infected regions. With the new generation of clones from our breeding programme we have obtained promising absolutely resistant clones, with high fruit quality, good fruit size and high regular cropping from end of August to beginning of October. We can say: the big problem of sharka is solved.

\section{REFERENCES}

Cambra, M., Capote, N., Myrta, A., Llacer, G. (2006). Plum pox virus and the estimated costs associated with sharka disease. Bulletin OEPP/EPPO Bulletin, 36 (2), 202-204.

Hamdorf, G., Hein, K. (1989). Untersuchungen über die Anfälligkeit von Pflaumen- und Zwetschensorten gegenüber dem Scharka-Virus (Plum pox virus). Landespflanzenschutzamt Mainz (Rheinland-Pfalz), Mainz. 166 pp. (in German).

Hartmann, W. (1998a). Hypersensitivity - a possibility for breeding sharka resistant plum hybrids. Acta Hort., 478, 429-431.

Hartmann, W. (1998b). New plum varieties from Hohenheim. Acta Hort., 478, 171-174.

Hartmann, W., Petruschke, M. (2000). Sharka resistant plums and prunes by utilization of hypersensitivity. Acta Hort., 538, 391-395.

Hartmann, W., Neumüller, M. (2010). Control of sharka by breeding. Acta Hort., 874, $229-237$.

Hartmann, W., Neumüller, M. (2013). The next generation of European plum cultivars resistant to Plum pox virus. Acta Hort., 985, 149-154.

Kegler, H., Hartmann, W. (1998). Present status of controlling conventional stains of plum pox virus. In: Hadidi, A., Khetarpal, R. K., Koganezawa H. (eds.). Plant Virus Disease Control. APS Press, St. Paul, MN, pp. 629-638.

Kegler, H., Fuchs, E., Grüntzig, M., Verderevskaja, T. D. (1986). Different types of resistance to plum pox virus. Acta Hort., 193, 201-206.

Kegler, H., Grüntzig, M., Fuchs E. (1994). A glasshouse test for detection resistance of plum genotypes to plum pox virus. Acta Hort., 538, 391-396.

Lichtenegger, L. (2012). Studien zur Züchtung von scharkaresistenten Klonen der Europäischen Pflaume Prunus domestica (L.) und zu deren Umweltstabilität. Ph.D. Thesis, Technischen Universität München, Wissenschaftszentrum Weihenstephan, Fakultät für Ernährung, Landnutzung und Umwelt. 127 pp. (in German).

Malinowski, T., Rozpara, E., Grzyb, Z. S. (2013). Evaluation of the susceptibility of several plum (Prunus domestica L.) cultivars to Plum Pox Virus (PPV) infection in the field. Sharka-like symptoms on 'Jojo' fruit are not related to PPV. J. Hort. Res., 21 (1), 61-65. 
Marn, M. V., Plesko, I. M., Altenbach, D., Bitterlin, W. (2014). Sensitivity of field tests, serological and molecular techniques for Plum Pox Virus detection in various tissues. Acta Agricult. Slowenia, 103 (1), 129-136.

Neumüller, M. (2005). Die Hypersensibilität der Europäischen Pflaume (Prunus domestica L.) gegenüber dem Scharkavirus (plum pox virus). Ph.D. Thesis, Hohenheim, Universität Hohenheim. 163 pp. (in German).

Neumüller, M., Hartmann, W. (2008). The phenotypical quantitative nature of hypersensitivity of European plum (Prunus domestica L.) against the Plum pox and its description using the hypersensitivity index. J. Hort. Sci., 35, 50-64.

Nemeth, M. (1994). History and importance of plum pox in stone fruit production. Bulletin OEPP/EPPO Bulletin, 24 (3), 525-536

Nemchinov, L., Creszenzi, A., Hadidi, A., Piazzolla, P., Verderevskaya, T. (1998). Present status of new cherry subgroup of plum pox virus (PPV-C). In: Hadidi, A., Khetarpal, R. K., Koganezawa, H. (eds). Plant Virus Disease Control, APS Press St. Paul, MN, pp. 629-638.
Scorza, R., Ravelonandro, M., Callahan, A. M., Cordts, J. M., Fuchs, M., Dunez, J., Gonsalves, D. (1994). Transgenic plums (Prunus domestica L.) express the plum pox virus coat protein gene. Plant Cell Rep., 14 (1), $18-22$.

Scorza, R., Georgi, L., Callahan, A., Petri, C., Hily, J., Dardick, C., Damsteegt, V., Ravelonandro, M. (2010). Hairpin Plum pox virus coat protein (hpPPV-CP) structure in 'HoneySweet' C5 plum provides PPV resistance when genetically engineered into plum (Prunus domestica) seedlings. In: Proceedings of the 21st International Conference on Virus and other Graft Transmissible Diseases of Fruit Crops, Neustadt, DEU, 5-10 July 2009. Julius Kühn-Institut. Sanitz, DEU, pp. 141-148.

Malinowski, T., Rozpara E., Grzyb Z. S. (2013). Evaluation of the susceptibility of several plum (Prunus domestica L.) cultivars to Plum Pox Virus (PPV) infection in the field. Sharka-like symptoms on 'Jojo' fruit are not related to PPV. J. Hort. Research, 21 (1), 61-65.

Zurawicz, E., Pruski K., Szymajda, M., Lewandowski, M., Seliga, L., Malinowski, T. (2013). Prunus domestica 'Jojo' - Good Parent for Breeding of New Plum Cultivars Resistant to Plum pox Virus. J. Agri. Sci., 5 (9), $1-5$.

Received 18 February 2019

Accepted in the final form 25 March 2019

\section{ŠARKAS IZTURĪGI PLŪMJU HIBRĪDI UN ŠK়IRNES NO PLŪMJU SELEKCIJAS PROGRAMMAS HOHENHEIMĀ}

Šarka (Plum pox vīruss, PPV) ir viens no visbīstamākajiem vīrusiem augḷkopībā. Arvien vairāk audzētāju ir neapmierināti ar šobrīd plašāk audzēto plūmju šķinnu izturību pret PPV. Izmantojot selekcijā hipersensitivitātes reakciju pret PPV, ir izveidota šķirne 'Jojo', kas ir absolūti rezistenta šķirne lauka apstākḷos. Jaunu, šarkas izturīgu šķinnu selekcija notiek trīs virzienos: ienākšanās laika pagarināšana, lielāki aug̣̦i un augstāka augḷu kvalitāte. Jaunajā selekcijas programmā ir iegūti daudzi hipersensitīvi kloni. Pēc izmēǵinājumiem, kas veikti dažādos reǵionos, daži vērtīgākie kloni prezentēti šajā rakstā. 